\title{
Synthesis of the Multisubstituted Halogenated Olefins via Cross- Coupling of Dihaloalkenes with Alkylzinc Bromides
}

\author{
Daniela Andrei and Stanislaw F. Wnuk \\ Department of Chemistry and Biochemistry, Florida International University, Miami, Florida 33199, \\ wnuk@fiu.edu
}

\begin{abstract}
The 1-fluoro-1-haloalkenes undergo Pd-catalyzed Negishi cross-couplings with primary alkylzinc bromides to give multisubstituted fluoroalkenes. The alkylation was trans-selective giving pure $Z$ fluoroalkenes in most cases. The highest yields were obtained with $\operatorname{Pd}_{2}\left(\mathrm{dba}_{3}\right.$ and $\mathrm{PdCl}_{2}(\mathrm{dppb})$ catalysts but the best stereochemical outcome was obtained with less reactive $\mathrm{Pd}\left(\mathrm{PPh}_{3}\right)_{4}$. The tertiary alkylzincs also produced desired fluoroalkenes in high yields. Coupling of 1,1-dichloroalkene with organozinc reagent resulted in the formation of mono-coupled product.
\end{abstract}

In the search for a more selective inhibitors of $S$-adenosyl-L-homocysteine (AdoHcy, A) hydrolase, ${ }^{1}$ we attempted syntheses of AdoHcy analogues with $5^{\prime}, 6^{\prime}$-olefin (or halovinyl) moieties incorporated in place of the sulfur atom (B. Figure 1). ${ }^{2}$ Based on the known ability of the enzyme to add water across $5^{\prime}, 6^{\prime}$-double bond, ${ }^{1 \mathrm{c}}$ we envisioned that such compounds should form "stable" complexes with the enzyme that would help to identify key binding groups at the active site of the enzyme that interact with the Hcy moiety and participate in subsequent elimination and hydrolytic activity steps.

Based on retrosynthetic analysis, we had previously attempted synthesis of analogues $\mathbf{B}$ (X $=\mathrm{H}$ ) by (a) construction of a new $\mathrm{C} 5^{\prime}-\mathrm{C} 6^{\prime}$ double bond via either Wittig or metathesis reactions or (b) formation of a new $\mathrm{C}^{\prime}$ '-C7' single bond via Pd-catalyzed cross-couplings between readily available $6^{\prime}$-halo(or stannyl)homovinyl adenosine ${ }^{1 \mathrm{a}}$ derivatives $(\mathbf{C}$ or $\mathbf{D})$ with the corresponding amino acid counterparts. ${ }^{2}$ Since subsequent addition of bromine across $\mathrm{C} 5{ }^{\prime}-\mathrm{C} 6{ }^{\prime}$ double bond in analogues of type $\mathbf{B}(\mathrm{X}=\mathrm{H})$ followed by dehydrobromination (DBU) found to be ineffective to yield vinyl 6'-bromides $\mathbf{B}(\mathrm{X}=\mathrm{Br})$, we turned our attention to direct synthesis of halovinyl analogues $\mathbf{B}$ via selective coupling employing dihalovinyl precursors of type $\mathbf{E}$.

The Pd-catalyzed cross-coupling reactions are powerful methods for the formation of carboncarbon bonds under conditions that are compatible with a broad range of functional group. ${ }^{3}$ However, despite the wide application of $\mathrm{C}_{\mathrm{sp}}-\mathrm{C}_{\mathrm{sp}}{ }^{2}$ and $\mathrm{C}_{\mathrm{sp}}{ }^{2-} \mathrm{C}_{\mathrm{sp}} 2$ couplings, couplings involving $\mathrm{C}_{\mathrm{sp}}{ }^{3}$ centers are less explored ${ }^{4}$ with the exception of couplings between $\mathrm{C}_{\mathrm{sp}}{ }^{2}$ as electrophiles and $\mathrm{C}_{\mathrm{sp}} 3$ as nucleophiles. $3 \mathrm{c}, 4 \mathrm{a}$ Moreover, the mono cross-coupling reactions of 1,1- dihalovinyl electrophiles with $\mathrm{C}_{\mathrm{sp}} 2$ or $\mathrm{C}_{\mathrm{sp}}$ nucleophiles are less common 5 and mono couplings between 1,1-dihalovinyl electrophiles and $\mathrm{C}_{\mathrm{sp}} 3$ nucleophiles are scarce. ${ }^{3 \mathrm{c}, 6}$ Panek et al. utilized a double coupling strategy with ( $\alpha$-iodo)vinyl silanes for the synthesis of trisubstituted alkenes in order to overcome difficulties in selective alkylation of vinyl dibromides. ${ }^{7}$ McCarthy ${ }^{8 \mathrm{a}}$ and Burton ${ }^{8 \mathrm{~b}}$ and their coworkers developed coupling between 1- 
bromo(or chloro)-1-fluoroalkenes with vinyl/aryl organostannanes and boranes in order to prepare the conjugated 1-substituted-1-fluoroolefins. 9

We were prompted to undertake model studies on Pd-catalyzed cross-coupling between vinyl dihalides and alkyl organometallics because the synthesis of analogue $\mathbf{B}$ (X = halogen) via Pdcatalyzed monoalkylation between dihalohomovinyl nucleoside (or carbohydrate) derivatives of type $\mathbf{E}$ and organozinc reagents was difficult. ${ }^{2,10}$ Moreover, there are only a few reports on selective monoalkylation of 1,1-dihaloalkenes. ${ }^{3 c, 6}$ Herein, we report a novel Negishi monoalkylation of 1-fluoro-1-haloalkenes, derived from the conjugated or unconjugated aldehydes and ketones, as well as 1,1-dichloroalkenes with alkylzinc bromides to provide access to the multisubstituted fluoro or chloro alkenes.

The 1- fluoro-1-haloalkenes 4-6 were chosen as precursors to study Pd-catalyzed Negishi $3 \mathrm{c}$ coupling with alkylzincs. We expected formation of monoalkylated fluoroalkenes in view of inertion of fluorides $3 \mathrm{a}$ towards couplings. The terminal dihaloalkenes 4-6 were prepared in high yields by the McCarthy's procedure ${ }^{11}$ which involves: (i) condensation of aldehydes 1ac and ketone 1d with sulfonyl-stabilized fluorophosphonates to give ( $\alpha$-fluoro)vinyl sulfones 2, (ii)radical stannyldesulfonylation with $\mathrm{Bu}_{3} \mathrm{SnH} / \mathrm{AIBN}$ to yield ( $\alpha$-fluoro)vinyl stannanes 3, and (iii) the halodestannylation ${ }^{1 \mathrm{a}}$ with NIS, $\mathrm{NBS}$ or $\mathrm{Cl}_{2}$ to give 1-fluoro-1-iodo- (4), 1fluoro-1-bromo- (5) or 1-fluoro-1-chloroalkenes (6), respectively (Scheme 1). It is noteworthy that dihaloalkenes of series $\mathbf{c}$ with a benzyloxy substituent at the allylic carbon are structural analogues of the dihalohomovinyl nucleoside or ribofuranosyl precursors of type $\mathbf{E}$ which also has an oxygen atom at $\gamma$ carbon from the halovinyl site.

Initially, we attempted couplings of the conjugated 1-fluorovinyl iodide 4a $(E / Z, 95: 5)$ with 2 equiv. of primary alkylzinc bromide $\left[\mathrm{BrZn}\left(\mathrm{CH}_{2}\right)_{3} \mathrm{CO}_{2} \mathrm{Et}\right]$ in the presence of $\mathrm{Pd}\left(\mathrm{PPh}_{3}\right)_{4}$ in benzene $\left(65^{\circ} \mathrm{C}, 10 \mathrm{~h}\right)$ which gave fluoro alkenoate $7 \mathbf{a}$ as a single $Z$ isomer $\left({ }^{3} J_{\mathrm{F}-\mathrm{H}(\text { trans })}=39.8\right.$ $\mathrm{Hz}$ ) in $70 \%$ yield (Scheme 2; Table 1, entry 1). The coupling occurred with retention of configuration via trans-selective alkylation (vide infra) but the $E / Z$ descriptors changed owing to the change in Cahn-Ingold-Prelog priority at the reaction center carbon. The 1-fluorovinyl bromide 5a and chloride $\mathbf{6 a}$ also underwent efficient couplings with $\mathrm{BrZn}\left(\mathrm{CH}_{2}\right)_{3} \mathrm{CO}_{2} \mathrm{Et}$ to give $7 \mathbf{a}(\mathrm{Z})$ in $70 \%$ and $80 \%$ yield (entries 3 and 4 ). The calculated yields based only on the conversion of $E$ isomers of $\mathbf{5 a}$ and $\mathbf{6 a}$ (from $E / Z, 93: 7$ mixtures) to $\mathbf{7 a}(Z)$ are $75 \%$ and $86 \%$, respectively. Analogous treatment of $\mathbf{4 a}(E / Z, 95: 5)$ with alkylzinc bromides containing double bond $\left[\mathrm{BrZn}\left(\mathrm{CH}_{2}\right)_{3} \mathrm{CH}=\mathrm{CH}_{2}\right]$ or acetal functionality $\left[\mathrm{BrZn}\left(\mathrm{CH}_{2}\right)_{2} \mathrm{CH}\left(\mathrm{OCH}_{2}\right)_{2}\right]$ gave $\mathbf{8 a}(Z)$ or $\mathbf{9 a}(Z)$, respectively (entries 5 and 6).

In order to optimalize reaction conditions, we tested efficiency of various Pd catalysts for such Negishi monoalkylation (Scheme 3). We found that tris(dibenzylideneacetone)palladium $\left[\mathrm{Pd}_{2}(\mathrm{dba})_{3}\right]$ and 1,4-bis(diphenylphosphinobutane)palladium chloride $\left[\mathrm{PdCl}_{2}(\mathrm{dppb})\right]$ gave smooth conversion of $4 \mathbf{a}$ into $9 \mathrm{a}$ in $2 \mathrm{~h}$ at $50{ }^{\circ} \mathrm{C}$. The $\mathrm{Pd}\left(\mathrm{PPh}_{3}\right)_{4}$ effected only $11 \%$ conversion of 4a into 9a under analogous conditions and $\mathrm{Pd}(\mathrm{OAc})_{2}$ and $\mathrm{PdCl}_{2}(\mathrm{dppf})$ were also less effective. Coupling of $\mathbf{4 a}$ with $\mathrm{BrZn}\left(\mathrm{CH}_{2}\right)_{3} \mathrm{CO}_{2} \mathrm{Et}$ in the presence of $\mathrm{PdCl}_{2}(\mathrm{dppb})$ gave improved yield of $7 \mathbf{a}(Z)(93 \%$, entry 2 vs. entry 1$)$ under milder conditions $\left(50{ }^{\circ} \mathrm{C}, 2 \mathrm{~h}\right)$.

The unconjugated 1-fluorovinyl halides $\mathbf{4 b}(E / Z, 78: 22)$ coupled with primary alkylzinc bromides in the presence of $\mathrm{Pd}\left(\mathrm{PPh}_{3}\right)_{4}$ to give $\mathbf{7 b}, \mathbf{8 b}$, and $9 \mathbf{b}$ in high yields (entries 9,13 , and 14). The conversion of $\mathbf{4 b}$ into $\mathbf{7 b}$ was achieved in higher yields under milder conditions with $\mathrm{PdCl}_{2}(\mathrm{dppb})$ as catalyst (entry 12$)$. The vinyl iodide $\mathbf{4 c}(E / Z, 75: 25)$ with benzyloxymethyl substituent at carbon $\beta$ (analogue of the nucleoside precursor of type $\mathbf{E}$ ) reacted with BrZn $\left(\mathrm{CH}_{2}\right)_{3} \mathrm{CH}=\mathrm{CH}_{2}\left[\mathrm{Pd}\left(\mathrm{PPh}_{3}\right)_{4}\right]$ to give the internal fluoroalkene $\mathbf{8 c}(Z)$ in moderate yield $(56 \%$, entry 17$)$ in addition to unchanged $4 \mathbf{c}$ with enriched $Z$ to $E$ ratio $(56: 44)$. The $\mathrm{PdCl}_{2}(\mathrm{dppb})$ catalyst not only increased the yield but also led to the formation of $\mathbf{8 c}$ as mixture of $E / Z$ isomers 
(20:80, 86\%; entry 18). Also bromide $\mathbf{5 c}$ yielded $\mathbf{8 c}$ as $E / Z$ mixture in high yield (entry 19$)$. The 1-fluorovinyl iodide $\mathbf{4 d}$ derived from acetophenone served as convenient starting material for the synthesis of multisubstituted alkenes ${ }^{12} \mathbf{7 d}(Z), \mathbf{8 d}(Z)$, and $9 \mathbf{d}(Z)$ (entries 20-23).

In order to learn more about the stereochemical outcome of the couplings, pure $E$ isomer and mixture enriched in $Z$ isomer $(E / Z, 15: 85)$ of 1-fluoro-1-iodoalkene $\mathbf{4 b}$ were prepared by separation of the corresponding ( $\alpha$-fluoro)vinyl stannanes $\mathbf{3 b}$ followed by the stereospecific iododestannylation. Treatment of $\mathbf{4 b}(E)$ with $\mathrm{BrZn}\left(\mathrm{CH}_{2}\right)_{3} \mathrm{CO}_{2} \mathrm{Et}$ or $\mathrm{BrZn}\left(\mathrm{CH}_{2}\right)_{2} \mathrm{CH}\left(\mathrm{OCH}_{2}\right)_{2}$ $\left[\mathrm{Pd}\left(\mathrm{PPh}_{3}\right)_{4} / 12 \mathrm{~h} / 65^{\circ} \mathrm{C}\right]$ resulted in smooth conversion (GC/MS, 19F NMR) to $7 \mathbf{b}(Z)$ or $\mathbf{9 b}$ $(Z)$ with isolated yields of $88 \%$ and $89 \%$, respectively (entries 10 and 15 ). On the other hand, analogous Negishi treatment of $\mathbf{4 b}(E / Z, 15: 85)$ yielded $7 \mathbf{b}(Z)$ or $9 \mathbf{b}(Z)$ in $14 \%$ (96\% conversion of $E$ isomer; entries 11 and 16) while the corresponding $7 \mathbf{b}(E)$ or $9 \mathbf{b}(E)$ were not formed. Prolonged reaction time and harsher conditions resulted in decomposition of the $4 b(Z)$ isomer (GC/MS, ${ }^{19}$ F NMR).

Generally, only in a few instances we observed formation (above detection limit ${ }^{13}$ of $1-$ $2 \%,{ }^{19} \mathrm{~F} \mathrm{NMR}$ ) of the corresponding $E$ isomers via cis-couplings (entries 18, 19, 21). For example alkylation of $\mathbf{4 c}$ (iodide) and $\mathbf{5 c}$ (bromide) in the presence of $\mathrm{PdCl}_{2}(\mathrm{dppb})$ produced $8 \mathbf{c}$ as $E / Z$ (20:80) mixture. These results are in agreement with trans-selective mono crosscoupling of 1,1-dihaloalkenes reported previously. $3 \mathrm{c}, 5,6,14$ Burton and coworkers showed that trans selectivity with 1-bromo-1-fluoroalkenes originates in the oxidative addition step since formation of the $E$-palladium complex is faster than the formation of the $Z$-palladium complex, which is hampered by steric hinderence of vicinal cis-substituent. ${ }^{14 \mathrm{a}}$ They applied this finding for the kinetic resolution of the $E$ and $Z$ coupling products. $8 \mathrm{~b}, 14$

The major by-product isolated from the coupling reactions resulted from the reductive homocoupling of dihalide components. For example, the selfcoupling product of $\mathbf{4 a}$, e.g. (Z,Z)-2,3-difluoro-1,4-diphenyl-1,3-butadiene 12, was isolated in $8 \%$ yield (16\% consumption of $4 \mathbf{a}$ ) from the reaction of $\mathbf{4 a}$ with $\mathrm{BrZn}\left(\mathrm{CH}_{2}\right)_{3} \mathrm{CH}=\mathrm{CH}_{2}$ (entry 5) as well as from reactions of $\mathbf{4 a}$ with branched alkylzincs.

We also examined the Pd-catalyzed coupling of 1,1-dihaloalkenes with branched alkylzincs. Thus, $\mathrm{PdCl}_{2}(\mathrm{dppb})$ was found to be effective for monoalkylation of $\mathbf{4 a}(E / Z, 95: 5)$ with tertBuZnBr (10a) to provide 11a (80\%; $3 \mathrm{~h}, 50{ }^{\circ} \mathrm{C}$; Scheme 4). The $\mathrm{Pd}_{2}(\mathrm{dba})_{3}$ and $\mathrm{Pd}\left(\mathrm{PPh}_{3}\right)_{4}$ catalysts were less effective leading to the formation of a significant amount of selfcoupling by-product 12 [e.g, 20\%, 40\% consumption of $\mathbf{4 a}$ for $\mathrm{Pd}\left(\mathrm{PPh}_{3}\right)_{4}$ ]. Interestingly, attempted couplings of $\mathbf{4 a}$ with secondary 2- or 3-pentylzinc bromides (10b or 10c) gave various amount of desired products $11 \mathrm{~b}$ or $11 \mathrm{c}$ (in the range of 5-50\%) along with the isomerization byproduct 11d $(35-70 \%)$ and selfcoupled diene $\mathbf{1 2}$ as well as reduced (Z)- $\beta$-fluorostyrene. Since purifications of desired products $\mathbf{1 1 b}$ and $\mathbf{1 1} \mathbf{c}$ from other byproducts (especially from 11d) turned out also to be difficult no further effort was undertaken to improve these reactions. Formation of byproducts derived from isomerization of the branched alkyl group during Negishi reaction is known. ${ }^{4 a}, 15$

We also investigated differentiation of the two halogens in 1,1-dibromo-, or 1,1dichloroalkenes for selective monoalkylation with alkylzincs. We found that $\beta, \beta$ dichlorostyrene 13 reacted $\left[\mathrm{PdCl}_{2}(\mathrm{dppf}) / \mathrm{THF} / 65^{\circ} \mathrm{C} / 14 \mathrm{~h}\right]$ with $\mathrm{BrZn}\left(\mathrm{CH}_{2}\right)_{3} \mathrm{CO}_{2} \mathrm{Et}$, to give a desired trisubstituted chloroalkene $\mathbf{1 5}(Z, 65 \%)$ in addition to the monocoupled/reduced byproduct 18 (22\%; Scheme 5). Analogous couplings in the presence of $\mathrm{PdCl}_{2}(\mathrm{dppb})$ produced $15(53 \%)$ and $18(15 \%)$ in addition to dialkylated product 17 (27\%). Similar couplings with more reactive $\beta, \beta$-dibromostyrene 14 produced mainly dialkylated 17 (57-69\%) in addition to $18(24-28 \%)$. 
In summary, we have developed Pd-catalyzed Negishi cross-coupling of 1-fluoro-1-(iodo, or bromo, or chloro)alkenes with alkylzincs, thus providing stereoselective access to the internal fluoroalkenes. The primary alkylzincs gave the best results but the tertiary alkylzincs also produced desired fluoroalkenes in high yields. The $\beta, \beta$-dichlorostyrene gave selective coupling to produce multisubstituted chloroalkenes. Application of 1,1-dihaloalkenes for selective double alkylation strategy which can be used for the synthesis of tetrasubstituted alkenes as well as synthesis of carbohydrate and nucleoside analogues of type $\mathbf{B}$ will be published elsewhere.

\section{Experimental Section}

Experimental procedures [Procedure A (synthesis of vinyl sulfones 2 via Wittig reaction), Procedure B (preparation of vinylstannane $\mathbf{3}$ via stannyldesulfonylation $\mathbf{2}$ ), Procedure C (synthesis of dihaloalkenes 4-6 via halodestannylation of 3), Procedure D (couplings of 1fluoro-1-haloalkenes 4-6 with alkylzincs) and Procedure E (couplings of 1,1-dichloro- 13 and 1,1-dibromoalkenes 14 with alkylzincs)] are described in the Supporting Information.

\section{Ethyl 5-Fluoro-6-phenyl-5(Z)-hexenoate (7a). Procedure D}

4-Ethoxy-4-oxobutylzinc bromide (0.5 M/THF; $0.60 \mathrm{~mL}, 0.30 \mathrm{mmol})$ was added via syringe to a stirring solution of $\mathbf{4 a}(E / Z, 95: 5 ; 50 \mathrm{mg}, 0.20 \mathrm{mmol})$ in dried benzene $(5 \mathrm{~mL})$ containing $\mathrm{Pd}\left(\mathrm{PPh}_{3}\right)_{4}(7 \mathrm{mg}, 0.006 \mathrm{mmol})$ under $\mathrm{N}_{2}$. The resulting mixture was heated at $65^{\circ} \mathrm{C}$ for $5 \mathrm{~h}$. Additional $\mathrm{Pd}\left(\mathrm{PPh}_{3}\right)_{4}(4.5 \mathrm{mg}, 0.004 \mathrm{mmol})$ and 4-ethoxy-4-oxobutylzinc bromide $(0.20 \mathrm{~mL}$, $0.10 \mathrm{mmol}$ ) were then added and heating was continued for an extra $5 \mathrm{~h}$. Volatiles were evaporated and the residue was partitioned $\left(\mathrm{NaHCO}_{3} / \mathrm{H}_{2} \mathrm{O} / / \mathrm{EtOAc}\right)$. The organic layer was washed (brine), dried $\left(\mathrm{Na}_{2} \mathrm{SO}_{4}\right)$, evaporated and chromatographed (hexane $\rightarrow 15 \%$ EtOAc/ hexane) to give $7 \mathbf{a}(Z)$ (33 mg, 70\%; 74\% based on the conversion of $E$ isomer only): ${ }^{1} \mathrm{H}$ NMR $\delta 1.26(\mathrm{t}, J=7.1 \mathrm{~Hz}, 3 \mathrm{H}), 1.95$ (quint, $J=7.3 \mathrm{~Hz}, 2 \mathrm{H}), 2.39-2.48(\mathrm{~m}, 4 \mathrm{H}), 4.15(\mathrm{q}, J=7.1 \mathrm{~Hz}$, $2 \mathrm{H}), 5.50(\mathrm{~d}, J=39.4 \mathrm{~Hz}, 1 \mathrm{H}), 7.15(\mathrm{t}, J=7.2 \mathrm{~Hz}, 1 \mathrm{H}), 7.30(\mathrm{t}, J=7.4 \mathrm{~Hz}, 2 \mathrm{H}), 7.45(\mathrm{~d}, J=$ $7.4 \mathrm{~Hz}, 2 \mathrm{H}) ;{ }^{13} \mathrm{C}$ NMR $\delta 14.6,22.1,32.7\left(\mathrm{~d},{ }^{2} J_{\mathrm{C}-\mathrm{F}}=26.9 \mathrm{~Hz}\right), 33.6,60.8,106.9\left(\mathrm{~d},{ }^{2} J_{\mathrm{C}-\mathrm{F}}=8.5\right.$ $\mathrm{Hz}), 127.2,128.7,128.9,134.0,160.2\left(\mathrm{~d},{ }^{1} J_{\mathrm{C}-\mathrm{F}}=266.7 \mathrm{~Hz}\right), 173.5 ;{ }^{19} \mathrm{~F}$ NMR $\delta-102.20(\mathrm{dt}$, $J=39.8,19.7 \mathrm{~Hz})$; $\mathrm{MS} \mathrm{m} / z 237\left(100 \%, \mathrm{MH}^{+}\right)$. Anal. Calcd. for $\mathrm{C}_{14} \mathrm{H}_{17} \mathrm{FO}_{2}$ (236.12): C, 71.16; H, 7.25; Found: C, 70.80; H, 7.16.

\section{3,3-Dimethyl-2-fluoro-1-phenyl-1-butene (11a)}

Treatment of $4 \mathbf{a}(E / Z, 95: 5,40 \mathrm{mg}, 0.16 \mathrm{mmol})$ with $\mathrm{PdCl}_{2}$ (dppb) (5\% molar) and tert-butylzinc bromide $(0.5 \mathrm{M} ; 0.6 \mathrm{~mL}, 0.32 \mathrm{mmol})$ as described in procedure $\mathrm{D}\left[3 \mathrm{~h}, 50{ }^{\circ} \mathrm{C}\right.$ ] gave $11 \mathrm{a}(23$ $\mathrm{mg}, 80 \%$; $95 \%$ based on GC-MS and $\left.{ }^{19} \mathrm{~F} \mathrm{NMR}\right):{ }^{1} \mathrm{H}$ NMR $\delta 1.15(\mathrm{~s}, 9 \mathrm{H}), 5.40(\mathrm{~d}, J=40.7 \mathrm{~Hz}$, 1H), 7.17-7.41 (m, 5H); ${ }^{19}$ F NMR $\delta-109.47$ (d, $J=40.7$ Hz); GC-MS m/z 178 [80\%, M+; $\left.t_{\mathrm{R}}=10.78 \mathrm{~min}\right]$. HRMS Calcd. for $\mathrm{C}_{12} \mathrm{H}_{15} \mathrm{~F}\left(\mathrm{M}+\mathrm{H}^{+}\right)$179.1237; Found: 179.1246 .

\section{(Z)-Ethyl 5-Chloro-6-phenyl-5-hexenoate (15). Procedure E}

4-Ethoxy-4-oxobutylzinc bromide $(0.5 \mathrm{M} ; 1.45 \mathrm{~mL}, 0.72 \mathrm{mmol})$ was added via syringe to a stirring solution of $13(50 \mathrm{mg}, 0.29 \mathrm{mmol})$ in dried THF (3 mL) containing $\mathrm{PdCl}_{2}(\mathrm{dppf})(24$ $\mathrm{mg}, 0.029 \mathrm{mmol}$ ) under $\mathrm{N}_{2}$. The resulting mixture was heated at $65^{\circ} \mathrm{C}$ overnight. Volatiles were evaporated and the residue was partitioned $\left(\mathrm{NaHCO}_{3} / \mathrm{H}_{2} \mathrm{O} / / \mathrm{EtOAc}\right)$. The organic layer was washed (brine), dried $\left(\mathrm{Na}_{2} \mathrm{SO}_{4}\right)$, evaporated and chromatographed (hexane $\rightarrow 10 \%$ EtOAc/hexane) to give 15 (47 mg, 65\%) and 18 (14 mg, 22\%). Compound 15 had: ${ }^{1} \mathrm{H}$ NMR $\delta 1.19(\mathrm{t}, J=7.1 \mathrm{~Hz}, 3 \mathrm{H}), 1.94$ (quint, $J=7.1 \mathrm{~Hz}, 2 \mathrm{H}), 2.30(\mathrm{t}, J=7.4 \mathrm{~Hz}, 2 \mathrm{H}), 2.47(\mathrm{t}, J=7.1$ $\mathrm{Hz}, 2 \mathrm{H}), 4.08(\mathrm{q}, J=7.1 \mathrm{~Hz}, 2 \mathrm{H}), 6.40(\mathrm{~s}, 1 \mathrm{H}), 7.28-7.52(\mathrm{~m}, 5 \mathrm{H}) ;{ }^{13} \mathrm{C}$ NMR $\delta 14.2,22.8$, $32.9,40.28,60.3,125.2,127.5,128.2,129.0,133.6,135.0,173.2 ;$ GC-MS $m / z .252$ (30\%, $\left.\mathrm{M}^{+}\left[{ }^{35} \mathrm{Cl}\right] ; t_{\mathrm{R}}=20.00 \mathrm{~min}\right)$. HRMS Calcd for $\mathrm{C}_{14} \mathrm{H}_{17} 35 \mathrm{ClO}_{2}\left(\mathrm{M}+\mathrm{H}^{+}\right): 253.0995$; Found: 253.0989. 


\section{Supplementary Material}

Refer to Web version on PubMed Central for supplementary material.

\section{Acknowledgements}

This investigation was partially supported by NIH/NIGMS S06GM08205. The support of US ARO

(W911NF-04-1-0022) for the purchase of $600 \mathrm{MHz}$ NMR spectrometer is acknowledged.

\section{References}

1. (a) Wnuk SF, Yuan CS, Borchardt RT, Balzarini J, De Clercq E, Robins MJ. J Med Chem 1994;37:3579-3587. [PubMed: 7932585]Yuan, C-S.; Liu, S.; Wnuk, SF.; Robins, MJ.; Borchardt, RT. Advances in Antiviral Drug Design. De Clercq, E., editor. 2. JAI Press; Greenwich: 1996. p. 41-88. (c) Wnuk SF. Mini-Rev Med Chem 2001;1:307-316. [PubMed: 12369977]

2. Wnuk, SF.; Lalama, J.; Andrei, D.; Garmendia, C.; Robert, J. S-Adenosylhomocysteine and $S$ ribosylhomocysteine analogues with sulfur atom replaced by the vinyl unit. Abstracts of Papers, Carbohydrate Division, 229th National Meeting of the American Chemical Society; San Diego, CA. March 13-17, 2005; CARB-035Jennifer, Lalama. MSc Thesis. Florida International University; 2004.

3. de Meijere, A.; Diederich, F., editors. Metal-Catalyzed Cross-Coupling Reactions. Wiley-VCH; Weinheim: 2004. Miyaura, N., editor. Top Curr Chem. 219. 2002. (c) Negishi EI, Hu Q, Huang Z, Qian M, Wang G. Aldrichimica Acta 2005;38:71-88.

4. For $\mathrm{C}_{\mathrm{sp}} \mathrm{C}_{\mathrm{sp}} 2$ (electrophile) $\mathrm{C}_{\mathrm{sp}} \mathrm{C}_{\mathrm{sp}} 3$ coupling see: (a)NegishiE-ILiuFDiederichFStangPJMetalCatalyzed Cross-Coupling ReactionsWiley-VCHWeinheim1998Chapter 1. 147Dai C, Fu GC. J Am Chem Soc 2001;123:2719-2724. [PubMed: 11456957]For $\mathrm{C}_{\mathrm{sp}} \mathrm{C}_{\mathrm{sp}}{ }^{2}$ (nucleophile) $\mathrm{C}_{\mathrm{sp}} \mathrm{C}_{\mathrm{sp}} \mathrm{s}^{3}$ see: (b) MenzelKFuGCJ Am Chem Soc200312537183719For $\mathrm{C}_{\mathrm{sp}}$ (nucleophile) $\mathrm{C}_{\mathrm{sp}} \mathrm{C}_{\mathrm{sp}} 3$ see: (c) Eckhardt M, Fu GC. J Am Chem Soc 2003;125:13642-13643. [PubMed: 14599185]For review on $\mathrm{C}_{\mathrm{sp}} \mathrm{C}_{\mathrm{sp}} 3 \mathrm{C}_{\mathrm{sp}}$ $\mathrm{C}_{\mathrm{sp}} 3$ couplings see: (c) Cárdenas DJ. Angew Chem Int Ed 2003;42:384-387.

5. (a) Roush WR, Moriarty KJ, Brown BB. Tetrahedron Lett 1990;31:6509-6512. (1,1-dibromoalkenes and vinylboronic acids). (b) Xu C, Negishi EI. Tetrahedron Lett 1999;40:431-434.Zeng X, Hu Q, Qian M, Negishi EI. J Am Chem Soc 2003;125:13636-13637. [PubMed: 14599182]Zeng X, Qian M, Hu Q, Negishi EI. Angew Chem Int Ed 2004;43:2259-2263.(1,1-dibromoalkenes and alkenyl zinc or zirconium). (c) Bryant-Friedrich A, Neidleim R. Synthesis 1995:1506-1510.Uenishi J, Matsui K. Tetrahedron Lett 2001;42:5353-5355.Shi JC, Zeng X, Negishi EI. Org Lett 2003;5:1825-1828. [PubMed: 12762662]Negishi EI, Shi JC, Zeng X. Tetrahedron 2005;61:9886-9895. [monoalkynylation of 1,1-dibromo(or chloro)alkenes]. (d) Shen W, Wang L. J Org Chem 1999;64:8873-8879. [PubMed: 11674792] (1,1-dibromoalkenes with aryl and vinylstannane). (e) Minato A. J Org Chem 1991;56:4052-4056. (1,1-chloroalkenes with arylzinc reagents)

6 . For the best of our knowledge the only successful Pd-catalyzed monoalkylation of vinyl dihalides was trans-selective monobutylation of 1,1-dichloro-2-phenylethene with $\mathrm{n}_{-} \mathrm{C}_{4} \mathrm{H}_{9} \mathrm{ZnCl}$ in $81 \%$ yield (dibutylation product was obtained in 11\%): (a) Minato A, Suzuki K, Tamao K. J Am Chem Soc 1987;109:1257-1258.Treatment of the (E/Z)-1-bromo-1-fluoroalkene with BuLi/ZnCl $2 / \mathrm{Pd}_{2}\left(\mathrm{PPh}_{3}\right)_{4}$ gave butylated Z-(fluoro)alkene and unchanged Z-isomer: (b) Lei X, Dutheuil G, Pannecoucke X, Quirion JC. Org Lett 2004;6:2101-2104. [PubMed: 15200295]For iron(III)-catalyzed couplings see: (c) Santos MD, Franck X, Hocquemiller R, Figadere B, Peyrat JF, Provot O, Brion JD, Alami M. Synlett 2004:2697-2700.

7. Arefolov A, Langille NF, Panek JS. Org Lett 2001;3:3281-3284. [PubMed: 11594814]

8. (a) Chen C, Wilcoxen K, Huang CQ, Strack N, McCarthy JR. J Fluorine Chem 2000;101:285-290. (b) Xu J, Burton DJ. Tetrahedron Lett 2002;43:2877-2879.

9. (a) Approaches in Ref. 8 required milder conditions than couplings of ( $\alpha$-fluoro)vinyl stannanes $9 \mathrm{~b}, \mathrm{c}$ and silanes $9 \mathrm{~d}$ with alkenyl/aryl halides which needed addition of $\mathrm{CuI}^{9 \mathrm{~b}, \mathrm{c}}$ and $\mathrm{CsF}^{9 \mathrm{~d}}$ in order to overcome inductive electron-withdrawing effects of the $\alpha$-fluorine atom that lower nucleophilicity of the stannanes and silanes. ${ }^{9 \mathrm{e}}$ On the other hand the same fluorine effect are expected to result in higher level of reactivity for $\alpha$-fluorinated electrophilic components. ${ }^{8}$ (b) Chen C, Wilcoxen K, Zhu YF, Kim KI, McCarthy JR. J Org Chem 1999;64:3476-3482. [PubMed: 11674468] (c) Liu Q, Burton DJ. Org Lett 2002;4:1483-1485. [PubMed: 11975609] (d) Hanamoto T, Kobayashi T. J Org Chem 
2003;68:6354-6359. [PubMed: 12895071] (e) Percy JM, Wilkes RD. Tetrahedron 1997;53:14749_ 14762.For the unexpectedly facile couplings of ( $\alpha$-fluoro)vinyl tris(trimethylsilyl)germanes see: (f) Wang Z, Gonzalez A, Wnuk SF. Tetrahedron Lett 2005;46:5313-5316.

10. (a) Only dialkylated and monoalkylated products have been isolated. ${ }^{2}$ (b) Panek and coworkers reported ${ }^{7}$ that their attempts to selectively methylate vinyl dibromides under Negishi, Stille, or Suzuki conditions were unsuccessful despite the fact that differentiation of the two halogen groups for the $\mathrm{C}_{\mathrm{sp}}{ }^{2}-\mathrm{C}_{\mathrm{sp}^{2}}$ and $\mathrm{C}_{\mathrm{sp}^{2}}{ }^{2} \mathrm{C}_{\mathrm{sp}}{ }^{2}$ cross-couplings are known. ${ }^{5}$

11. McCarthy JR, Huber EW, Le TB, Laskovics M, Matthews DP. Tetrahedron 1996;52:45-58.

12. Itami K, Nokami T, Ishimura Y, Mitsudo K, Kamei T, Yoshida JI. J Am Chem Soc 2001;123:1157711585. [PubMed: 11716711] (synthesis of tetrasubstituted alkenes via sequential couplings)

13. Robins MJ, Sarker S, Wnuk SF. Nucleosides Nucleotides 1998;17:785-790.

14. (a) Zhang X, Burton DJ. J Fluorine Chem 2001:47-54. (b) Xu J, Burton DJ. J Org Chem 2005;70:4346-4353. [PubMed: 15903310]

15. Hayashi T, Konishi M, Kobori Y, Kumada M, Higuchi T, Hirotsu K. J Am Chem Soc 1984;106:158163. 
<smiles>Nc1ncnc2c1ncn2[C@@H]1O[C@H](SCC[C@H](N)C(=O)O)[C@@H](O)[C@H]1O</smiles>

A<smiles></smiles>

B

$\mathrm{X}=\mathrm{H}$ or halogen

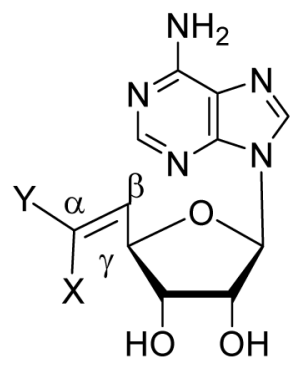

C $Y=I$ or $\mathrm{Br}, \mathrm{X}=\mathrm{H}$

D $Y=\mathrm{Bu}_{3} \mathrm{Sn}, \mathrm{X}=\mathrm{H}$ $\mathrm{E} Y=\mathrm{X}=\mathrm{Br}$

FIGURE 1.

$S$-Adenosyl-L-homocysteine $\mathbf{A}$ and structure of the analogues $\mathbf{B}$ with sulfur atom replaced by "vinyl unit" 


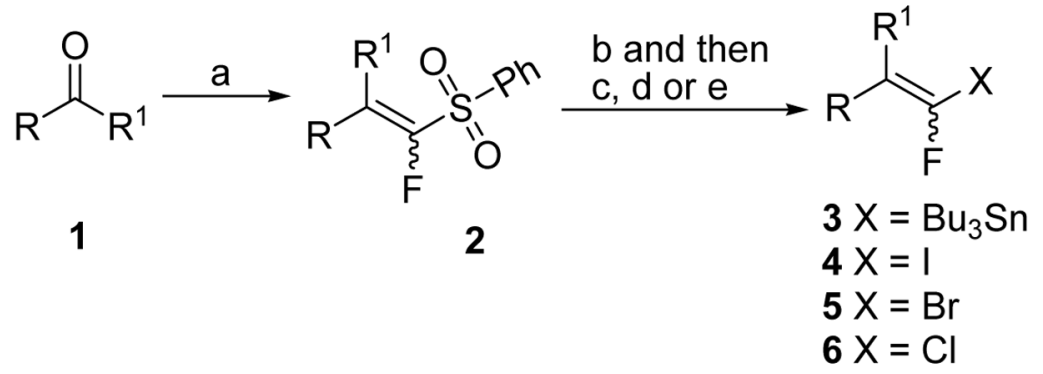

${ }^{a}$ Key: (a) $\mathrm{PhSO}_{2} \mathrm{CHFPO}(\mathrm{OEt})_{2} / \mathrm{LHMDS} / \mathrm{THF} /-78{ }^{\circ} \mathrm{C}$; (b) $\mathrm{Bu}_{3} \mathrm{SnH} /$ AIBN/benzene/ $\Delta$; (c) NIS/ $\mathrm{CH}_{2} \mathrm{Cl}_{2}$; (d) NBS/ $\mathrm{CH}_{2} \mathrm{Cl}_{2} ;$ (e) $\mathrm{Cl}_{2} / \mathrm{CH}_{2} \mathrm{Cl}_{2}$.

\begin{tabular}{cll} 
Compds 1-6 & \multicolumn{1}{c}{$\mathrm{R}$} & $\mathrm{R}^{1}$ \\
\hline a & $\mathrm{Ph}$ & $\mathrm{H}$ \\
b & $\mathrm{PhCH}_{2} \mathrm{CH}_{2}$ & $\mathrm{H}$ \\
c & $\mathrm{PhCH}_{2} \mathrm{OCH}_{2}$ & $\mathrm{H}$ \\
d & $\mathrm{Ph}$ & $\mathrm{CH}_{3}$
\end{tabular}

Scheme 1.

Stereoselective synthesis of 1-fluoro-1-haloalkenes 4-6 ${ }^{a}$ 


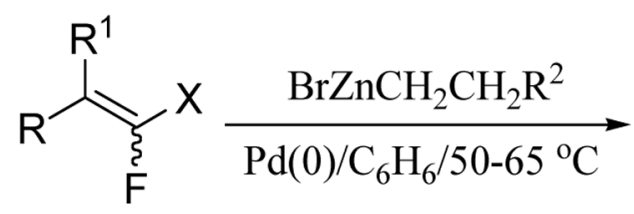

$$
\begin{aligned}
& 4 X=1 \\
& 5 X=B r \\
& 6 X=C l
\end{aligned}
$$<smiles>[R]CCC(F)=C([R])[R]</smiles>

$7 \mathrm{R}^{2}=\mathrm{CH}_{2} \mathrm{CO}_{2} \mathrm{Et}$

$8 \mathrm{R}^{2}=\mathrm{CH}_{2} \mathrm{CH}=\mathrm{CH}_{2}$

$9 \mathrm{R}^{2}=\mathrm{CH}\left(\mathrm{OCH}_{2}\right)_{2}$

Scheme 2.

Couplings of 1-fluoro-1-haloalkenes with alkylzincs ${ }^{a}$

${ }^{a}$ Key: See Scheme 1 for description of $\mathrm{R}$ and $\mathrm{R}^{1}$. 


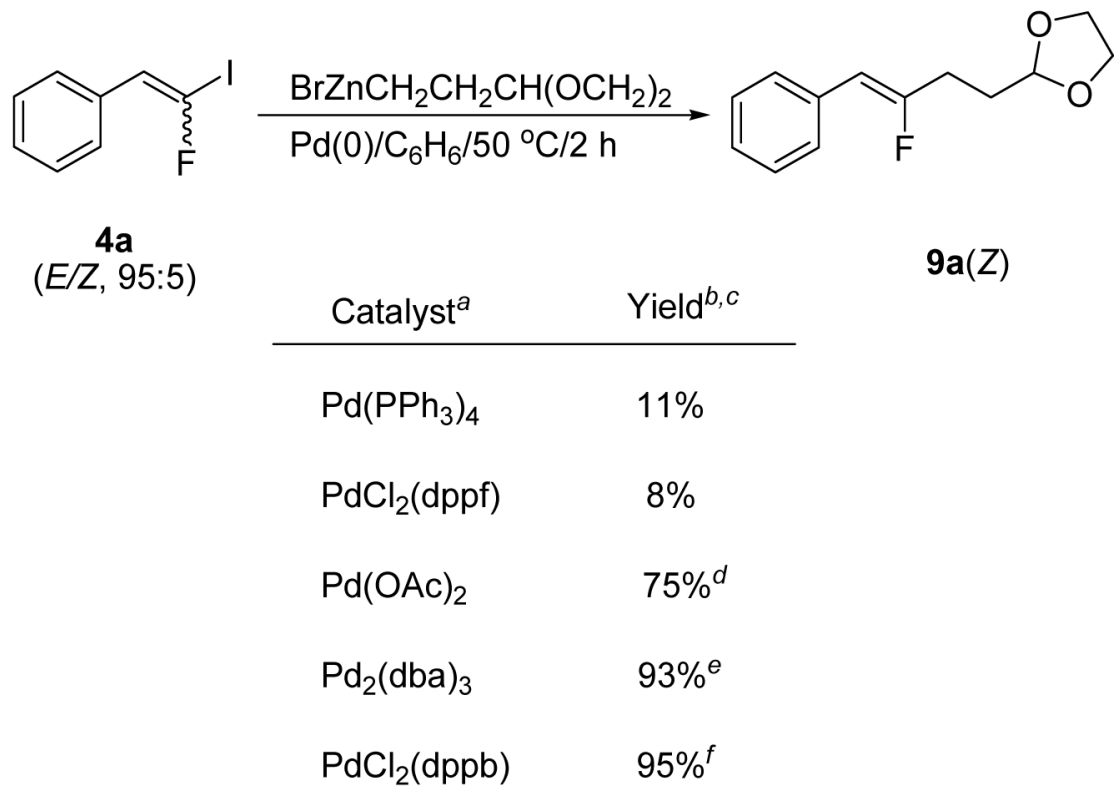

Scheme 3.

Effect of the Pd catalysts on the efficiency of coupling $a$

Key: ${ }^{a} 5 \%$ molar; ${ }^{b} \mathrm{GC} / \mathrm{MS}$ and ${ }^{19} \mathrm{~F}$ NMR; ${ }^{c}$ only $Z$ product was detected; $d 95 \%$ after 3.5 $\mathrm{h} ;{ }^{e}$ Isolated yield $92 \% ;{ }^{f}$ Isolated yield $94 \%$. 
<smiles>FC(I)=Cc1ccccc1</smiles>
$4 a$ $(E / Z, 95: 5)$

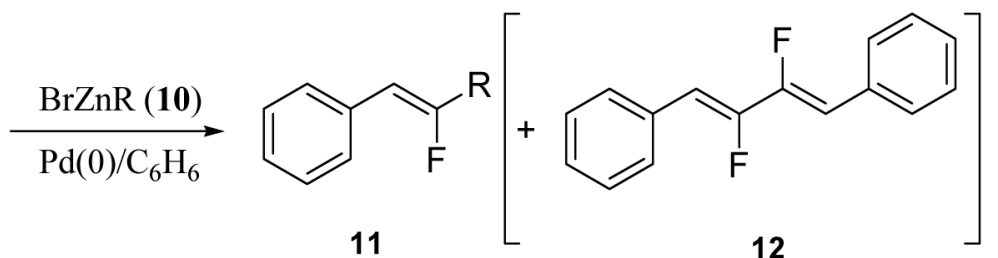

12

Scheme 4. Couplings with branched alkyzincs

Compounds 10, 11: Series a $\mathrm{R}=$ tert-Bu

b $\mathrm{R}=2$-pentyl

c $\mathrm{R}=3$-pentyl

d $\mathrm{R}=n$-pentyl 


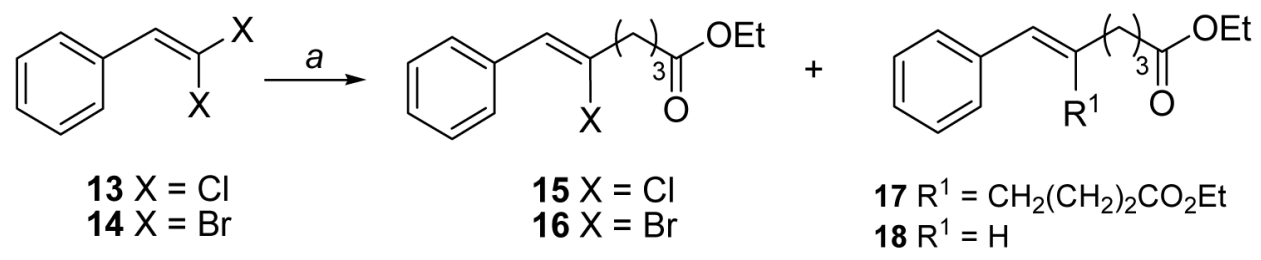

Scheme 5.

Couplings with 1,1-dibromo- and 1,1-dichloroalkenes ${ }^{a}$

${ }^{a}$ Key: (a) $\mathrm{BrZn}\left(\mathrm{CH}_{2}\right)_{3} \mathrm{CO}_{2} \mathrm{Et} / \mathrm{PdCl}{ }_{2}$ (dppf)/THF $/ 65^{\circ} \mathrm{C}$ (oil-bath) 


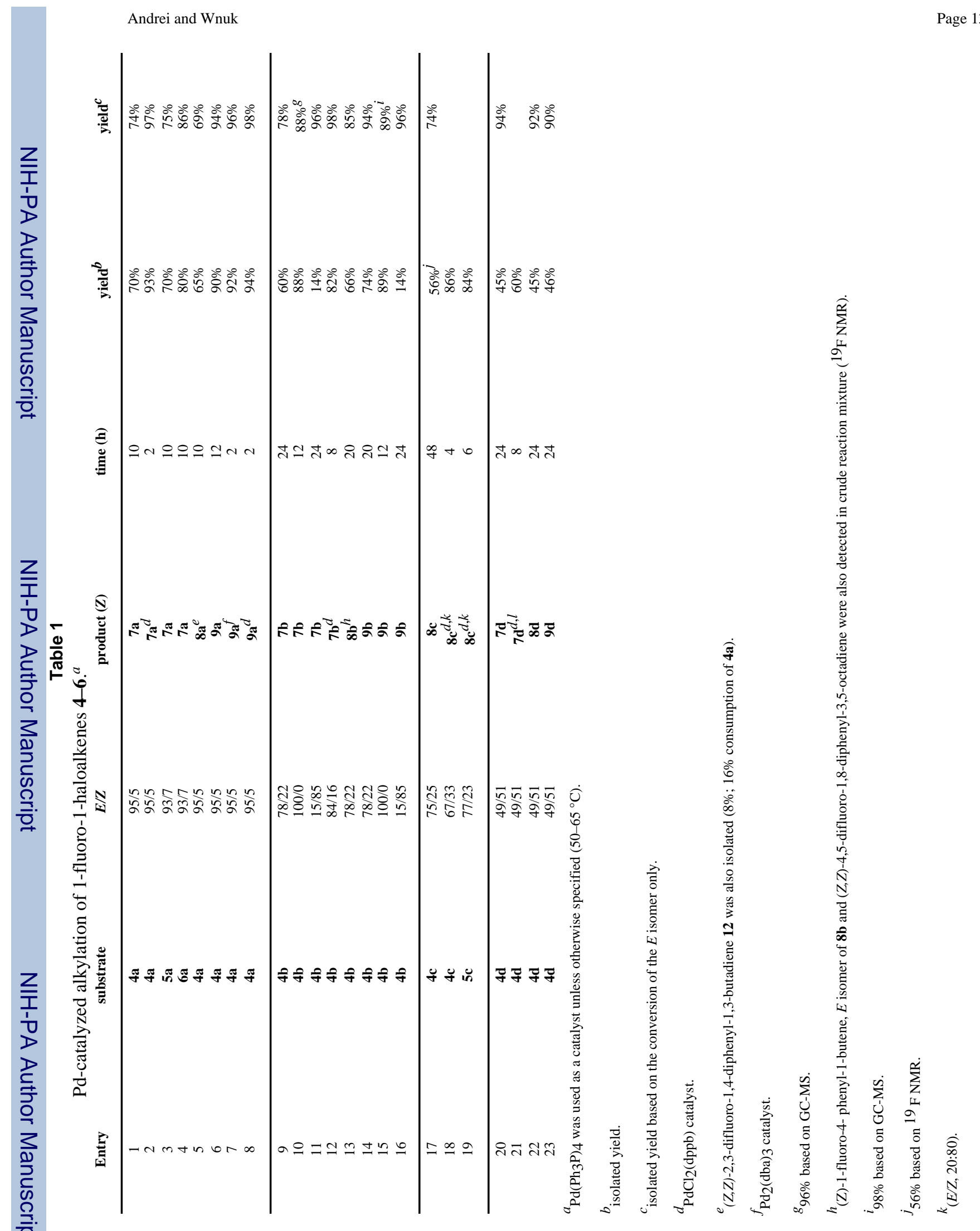


